\title{
Microbacterium koreense sp. nov., from sea water in the South Sea of Korea
}

Correspondence

Jung-Sook Lee

jslee@kribb.re.kr

\author{
Jung-Sook Lee, Keun Chul Lee and Yong-Ha Park \\ Korean Collection for Type Cultures, Korea Research Institute of Bioscience and \\ Biotechnology, 52 Oeundong, Yusong, Daejeon 305-333, Korea
}

The genus Microbacterium was first proposed as comprising a diverse collection of Gram-positive, non-spore-forming rods isolated during studies on lactic acid-producing bacteria by Orla-Jensen (1919). It was recognized as a very heterogeneous group. However, extensive systematic studies have resolved these relationships and emended the description of the genus Microbacterium. Its description was first emended in 1983 (Collins et al., 1983) and then emended again in 1998 (Takeuchi \& Hatano, 1998a). The genera Microbacterium and Aureobacterium are phylogenetically intermixed, although they are separate taxa on the basis of (primarily) cell-wall differences. The presence of the L-diamino acid L-lysine in the cell wall is characteristic of Microbacterium and the presence of the D-diamino acid D-ornithine in the cell wall is characteristic of Aureobacterium. The other chemotaxonomic and phenotypic characteristics of the members of the two genera have shown very similar profiles. On the basis of these data, Takeuchi \& Hatano (1998a) emended the descriptions of the genera Microbacterium and Aureobacterium, uniting them in a redefined genus Microbacterium.

Published online ahead of print on 7 October 2005 as DOI 10.1099/ ijs.0.63854-0.

The GenBank/EMBL/DDBJ accession number for the 16S rRNA gene sequence of strain JS53-2 $2^{\top}$ is AY962574.

Photomicrographs of strain JS53-2 ${ }^{\top}$, an extended phylogenetic tree and a table of whole-cell fatty acid profiles are available as supplementary material in IJSEM Online.
Members of the genus Microbacterium are found in various environments, including soil, water, plants, milk products and human clinical samples. During the course of our studies on microbial diversity in the sea water of Korea, we found yellow-pigmented bacteria in sea water from the South Sea of Korea (the Korea Strait); experiments were performed to determine the morphological, biochemical and phylogenetic characteristics of those isolates. On the basis of the results, we propose that these isolates be assigned to a novel species.

Strains JS53-2 ${ }^{\mathrm{T}}$ and JS53-5 were isolated (on tryptic soy agar) from sea water from the South Sea of Korea. The isolates and reference strains Microbacterium terregens KCTC $19034^{\mathrm{T}}$ (=IFO $\left.12961^{\mathrm{T}}\right)$, Microbacterium lacticum KCTC $9230^{\mathrm{T}}\left(=\mathrm{DSM} 20427^{\mathrm{T}}\right)$, Microbacterium aurum KCTC $19091^{\mathrm{T}}\left(=\mathrm{IFO} 15204^{\mathrm{T}}\right)$ and Microbacterium schleiferi KCTC $19095^{\mathrm{T}}$ ( $=$ IFO $15075^{\mathrm{T}}$ ) were cultured on tryptic soy agar for $48 \mathrm{~h}$ at $30^{\circ} \mathrm{C}$.

The cell morphology was examined by using light microscopy. Motility was determined with an optical microscope, using the hanging drop technique (Skerman, 1967). Anaerobic growth was recorded in an anaerobic chamber $\left(\mathrm{CO}_{2} / \mathrm{H}_{2} /\right.$ $\mathrm{N}_{2}, 7: 7: 86$; Forma Scientific) on tryptic soy agar for up to 1 week. Growth in the presence of various concentrations of added $\mathrm{NaCl}(0 \cdot 5,1,2,5,10,15$ and $20 \%$, w/v) was tested with nutrient broth (Difco) as the basal medium. Growth at different temperatures was observed in trypticase soy broth at $10,15,20,25,30,37,42$ and $50^{\circ} \mathrm{C}: 10 \mathrm{ml}$ trypticase soy 
broth was adjusted to $\mathrm{pH}$ values ranging from $4 \cdot 0$ to $11 \cdot 0$ (100 mM citric acid/200 mM $\mathrm{Na}_{2} \mathrm{HPO}_{4}$ at $\mathrm{pH} 4 \cdot 0-5 \cdot 0$, $100 \mathrm{mM} \mathrm{Na}_{2} \mathrm{HPO}_{4} / \mathrm{NaH}_{2} \mathrm{PO}_{4}$ buffer at $\mathrm{pH} 6 \cdot 0-8 \cdot 0,100 \mathrm{mM}$ $\mathrm{NaHCO}_{3} / \mathrm{Na}_{2} \mathrm{CO}_{3}$ buffer at $\mathrm{pH} 9 \cdot 0-10 \cdot 0$ and $50 \mathrm{mM}$ $\mathrm{Na}_{2} \mathrm{HPO}_{4} / 100 \mathrm{mM} \mathrm{NaOH}$ buffer at $\mathrm{pH} 11 \cdot 0$ ), using a method based on that of Yumoto et al. (1998). Growth was estimated by monitoring the $\mathrm{OD}_{600}$. Physiological and biochemical characteristics were determined using API 20E, API 20NE and API 50 CHB kits (bioMérieux). All API tests were performed in accordance with the manufacturer's instructions. Catalase activity was determined by means of bubble production from $3 \%(\mathrm{v} / \mathrm{v}) \mathrm{H}_{2} \mathrm{O}_{2}$, while oxidase activity was determined using $1 \%(\mathrm{w} / \mathrm{v})$ tetramethyl- $p$ phenylenediamine.

Table 1. Distinctive characteristics of the isolates and related Microbacterium species

Strains: 1, M. lacticum KCTC $9230^{\mathrm{T}}$; 2, M. terregens KCTC $19034^{\mathrm{T}}$; 3, M. aurum KCTC 19091 ${ }^{\mathrm{T}}$; 4 , M. schleiferi KCTC $19095^{\mathrm{T}}$; 5, M. koreense JS53-2 ${ }^{\mathrm{T}}$ and JS53-5. Data are from this study, from Takeuchi \& Hatano (1998a, b) and from Behrendt et al. (2001). Abbreviations: +, positive; W, weakly positive; - , negative. For all strains, the results are positive for growth in $0.5 \% \mathrm{NaCl}$, aesculin hydrolysis and acid production from glucose, fructose, mannose, mannitol, cellobiose and maltose; all strains are negative for motility, gelatin hydrolysis and oxidase.

\begin{tabular}{|c|c|c|c|c|c|}
\hline Characteristic & 1 & 2 & 3 & 4 & 5 \\
\hline Colony colour & Yellow & Yellow & Yellow & Yellow & Light yellow \\
\hline Anaerobic growth & + & - & + & - & - \\
\hline Catalase & + & - & + & + & + \\
\hline Temperature range $\left({ }^{\circ} \mathrm{C}\right)$ & $15-30$ & $20-30$ & $10-42$ & $10-42$ & $20-37$ \\
\hline Growth in $\mathrm{NaCl}$ at $5 \%$ & - & - & + & - & + \\
\hline $\mathrm{H}_{2} \mathrm{~S}$ production & + & - & - & - & - \\
\hline \multicolumn{6}{|l|}{ Acid production from: } \\
\hline Glycerol & + & - & - & $\mathrm{W}$ & - \\
\hline D-Xylose & - & + & - & + & $\mathrm{W}$ \\
\hline Methyl $\beta$-D-xyloside & - & + & - & - & - \\
\hline Galactoside & + & - & + & + & $\mathrm{w}$ \\
\hline Rhamnose & - & - & + & - & + \\
\hline $\mathrm{N}$-Acetylglucosamine & + & - & + & - & + \\
\hline Arbutin & + & - & - & - & - \\
\hline Salicin & + & - & - & - & - \\
\hline Lactose & + & - & - & $\mathrm{W}$ & - \\
\hline Melibiose & - & + & - & - & - \\
\hline Sucrose & - & + & + & + & + \\
\hline Trehalose & - & + & + & + & $\mathrm{w}$ \\
\hline Starch & + & - & + & - & + \\
\hline Raffinose & - & + & + & - & - \\
\hline Glycogen & + & - & - & $\mathrm{W}$ & $\mathrm{w}$ \\
\hline \multicolumn{6}{|l|}{ Assimilation of: } \\
\hline Glucose & + & - & + & - & + \\
\hline Mannose & + & - & + & - & + \\
\hline Mannitol & + & - & + & - & + \\
\hline$N$-Acetylglucosamine & + & - & $\mathrm{W}$ & - & + \\
\hline Maltose & - & - & + & - & + \\
\hline DNA G $+\mathrm{C}$ content $(\mathrm{mol} \%)$ & 71 & 68 & $69 \cdot 2$ & 68 & 68 \\
\hline Menaquinones & $\begin{array}{l}\text { MK-11, } \\
\text { MK-12 }\end{array}$ & $\begin{array}{l}\text { MK-12, } \\
\text { MK-13 }\end{array}$ & $\begin{array}{l}\text { MK-11, } \\
\text { MK-12 }\end{array}$ & $\begin{array}{l}\text { MK-10, } \\
\text { MK-11, } \\
\text { MK-12 }\end{array}$ & $\begin{array}{l}\text { MK-11, } \\
\text { MK-12 }\end{array}$ \\
\hline Cell-wall diamino acid $^{*}$ & Lys & Orn & Lys & Orn & Lys \\
\hline Cell-wall sugars $\dagger$ & $\begin{array}{c}\text { Rha, Man, } \\
\text { Gal }\end{array}$ & $\begin{array}{c}\text { Rha, Gal, } \\
\text { 6dTal }\end{array}$ & $\begin{array}{c}\text { Fuc, Gal, } \\
\text { Glc }\end{array}$ & $6 \mathrm{dTal}$ & Gal, Xyl \\
\hline
\end{tabular}

${ }^{\star}$ Lys, Lysine; Orn, ornithine.

$\nmid 6 \mathrm{dTal}$, 6-Deoxytalose; Fuc, fucose; Gal, galactose; Man, mannose; Rha, rhamnose; Xyl, xylose. 
The isolates were aerobic, non-motile, rod-shaped and Gram-positive. In old cultures, the rods became shorter or spherical (see Supplementary Fig. S1 available in IJSEM Online). Colonies were circular, convex with entire margins, moist, shiny and light yellow in colour. The isolates grew neither in an anaerobic chamber at $37^{\circ} \mathrm{C}$ nor with $\mathrm{NaCl}$ at concentrations above $10 \%$. Optimum growth was observed without added $\mathrm{NaCl}$. The isolates grew at $20-37^{\circ} \mathrm{C}$ and at $\mathrm{pH} 6 \cdot 0-8 \cdot 0$. The optimum growth temperature and $\mathrm{pH}$ were $30^{\circ} \mathrm{C}$ and $\mathrm{pH}$ 7. The morphological, physiological and chemotaxonomic characteristics of the isolates are different from those of phylogenetically closely related Microbacterium species (Table 1).

For total analysis of the cellular fatty acids, the cells were cultured on tryptic soy agar for $48 \mathrm{~h}$ at $30^{\circ} \mathrm{C}$ and then the fatty acids were extracted according to the Microbial Identification System instructions, as described previously (Lee et al., 1996; Yang et al., 1993). The isoprenoid quinones were extracted with chloroform/methanol $(2: 1, \mathrm{v} / \mathrm{v})$ and purified by using TLC on Merck Kieselgel $60 \mathrm{~F}_{254}$ plates $(20 \times 20 \mathrm{~cm}$, $0.5 \mathrm{~mm}$ thickness) using petroleum ether/diethyl ether $(9: 1, \mathrm{v} / \mathrm{v})$ as the solvent. The identities of the quinones were determined by using reversed-phase HPLC analysis, as described by Shin et al. (1996). The whole-cell sugars were determined by using the method of Komagata \& Suzuki (1987). Analysis of the diamino acid in peptidoglycan hydrolysates was carried out as described by Bousfield et al. (1985) on a cellulose TLC plate.

The whole-cell fatty acid profiles for the strains are shown in Supplementary Table S1 (available in IJSEM Online). The major fatty acids in the isolates and in related Microbacterium species were anteiso- $\mathrm{C}_{15: 0}$, anteiso- $\mathrm{C}_{17: 0}$ and iso$\mathrm{C}_{16: 0}$. The cell-wall sugars and the major menaquinones of the isolates were found to be galactose and xylose and MK11 and MK-12, respectively. Differential characteristics of the isolates and reference strains are shown in Table 1. The diamino acid in cell-wall hydrolysates of the isolates and reference strains M. lacticum KCTC $9230^{\mathrm{T}}$ and M. aurum KCTC $19091^{\mathrm{T}}$ was lysine, while that of reference strains M. terregens KCTC $19034^{\mathrm{T}}$ and M. schleiferi KCTC $19095^{\mathrm{T}}$ was ornithine.

DNA was extracted and purified by using a modified version of the method described by Marmur (1961). The G+C content of the DNA was determined using the HPLC method described by Tamaoka \& Komagata (1984). The DNA G $+\mathrm{C}$ contents of the isolates and reference strains M. lacticum KCTC $9230^{\mathrm{T}}$, M. terregens KCTC $19034^{\mathrm{T}}, M$. aurum KCTC $19091^{\mathrm{T}}$ and M. schleiferi KCTC $19095^{\mathrm{T}}$ were $68,71,68,69$ and $68 \mathrm{~mol} \%$, respectively.

Two universal primers (9F and 1492R) described by Stackebrandt \& Liesack (1993) were used for PCR amplification of the 16S rRNA gene, and the amplified PCR product was purified using a QIAquick PCR purification kit (Qiagen). The purified 16S rRNA gene was then sequenced using an ABI Prism BigDye Terminator cycle sequencing ready reaction kit (Applied Biosystems), with an automatic DNA sequencer (model 377; Applied Biosystems). Nearly complete $16 \mathrm{~S}$ rRNA gene sequences (1435 bp) were determined for isolates JS53-2 ${ }^{\mathrm{T}}$ and JS53-5, and aligned with the $16 \mathrm{~S}$ rRNA gene sequences of representatives of the genus Microbacterium and related taxa, using CLUSTAL W software (Thompson et al., 1994). A phylogenetic tree was constructed using the neighbour-joining method (Saitou \& Nei, 1987) based on distance-matrix data. Evolutionary distances were calculated using the model of Jukes \& Cantor (1969). The PHYLIP software package (Felsenstein, 1993) was used for all analyses. The topology of the phylogenetic tree was evaluated using a bootstrap analysis (Felsenstein, 1985) of the neighbour-joining method, based on 1000 replications. The 16S rRNA gene sequences of the strains were compared with those of closely related reference strains. A phylogenetic tree indicated that isolates JS53-2 $2^{\mathrm{T}}$ and JS53-5 belong to the genus Microbacterium (Fig. 1; an extended version of this tree is available as Supplementary Fig. S2 in IJSEM Online).

Isolates JS53-2 ${ }^{\mathrm{T}}$ and JS53-5 had identical 16S rRNA gene sequences and morphological, physiological and chemotaxonomic characteristics, implying that they might be members of the same species. They were phylogenetically closely related to M. lacticum DSM $20427^{\mathrm{T}}(98 \cdot 1 \%$ sequence similarity), M. schleiferi IFO $15075^{\mathrm{T}}(98 \cdot 1 \%$ sequence similarity), M. terregens IFO $12961^{\mathrm{T}}$ (97.9\% sequence similarity) and M. aurum IFO $15204^{\mathrm{T}}$ ( $97 \cdot 4 \%$ sequence similarity).

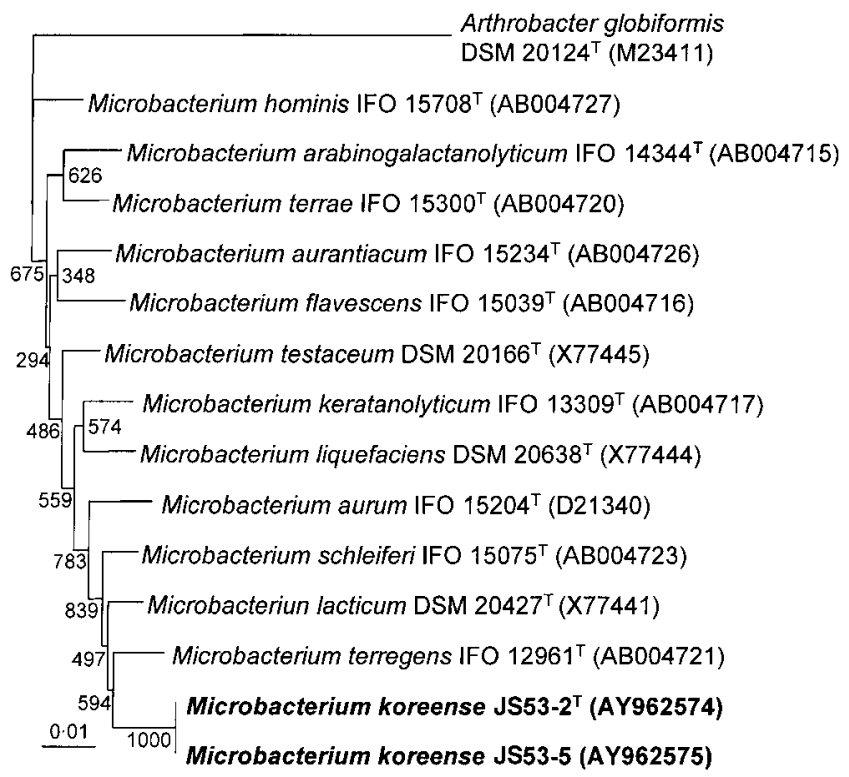

Fig. 1. Phylogenetic tree, based on 16S rRNA gene sequences, showing the position of isolates JS53-2 ${ }^{\top}$ and JS535 with respect to other species from genus Microbacterium and related taxa. Arthrobacter globiformis served as the external reference. Numbers indicate bootstrap values. Bar, 0.01 accumulated changes per nucleotide. An extended version of this tree is available as Supplementary Fig. S2 in IJSEM Online. 
Table 2. DNA-DNA reassociation values for the isolates and related Microbacterium species

\begin{tabular}{|c|c|c|c|c|c|c|}
\hline \multirow[t]{2}{*}{ Strain } & \multicolumn{6}{|c|}{ Reassociation (\%) with labelled DNA from: } \\
\hline & 1 & 2 & 3 & 4 & 5 & 6 \\
\hline 1. JS53-2 ${ }^{\mathrm{T}}$ & 100 & 102 & 18 & 21 & 15 & 20 \\
\hline 2. JS53-5 & 93 & 100 & 22 & 14 & 15 & 17 \\
\hline 3. M. lacticum KCTC $9230^{\mathrm{T}}$ & 20 & 16 & 100 & 15 & 20 & 25 \\
\hline 4. M. terregens KCTC $19034^{\mathrm{T}}$ & 19 & 23 & 27 & 100 & 21 & 13 \\
\hline 5. M. aurum KCTC $19091^{\mathrm{T}}$ & 19 & 13 & 18 & 14 & 100 & 22 \\
\hline 6. M. schleiferi KCTC $19095^{\mathrm{T}}$ & 12 & 16 & 19 & 25 & 29 & 100 \\
\hline
\end{tabular}

The levels of sequence similarity between these strains and other Microbacterium species ranged from $93 \cdot 2$ to $98 \cdot 1 \%$.

DNA-DNA hybridization was carried out by means of fluorometric hybridization in microdilution wells, using biotinylated DNA (Ezaki et al., 1989). As shown in Table 2, the DNA-DNA reassociation values between isolates JS53$2^{\mathrm{T}}$ and JS53-5 and reference strains $M$. lacticum KCTC $9230^{\mathrm{T}}$, M. terregens KCTC $19034^{\mathrm{T}}$, M. aurum KCTC $19091^{\mathrm{T}}$ and M. schleiferi KCTC $19095^{\mathrm{T}}$ were less than $23 \%$. The phylogenetic definition of a species generally involves 'strains with approximately $70 \%$ or greater DNA-DNA relatedness' (Wayne et al., 1987). According to currently available data, organisms with a sequence similarity of less than $97 \cdot 0 \%$ will not reassociate to more than $60 \%$, no matter which hybridization method is applied (Stackebrandt \& Goebel, 1994; Rossello-Mora \& Amann, 2001; Stackebrandt et al., 2002). Therefore, the phylogenetic and DNA-DNA hybridization results from this work demonstrate that the isolates are phylogenetically closer to members of the genus Microbacterium and are not related to any previously described Microbacterium species at the species level.

On the basis of the above results, a novel species, Microbacterium koreense sp. nov., is proposed.

\section{Description of Microbacterium koreense sp. nov.}

Microbacterium koreense (ko.re.en'se. N.L. neut. adj. koreense pertaining to Korea, where the type strain was isolated).

Aerobic, non-motile, Gram-positive organism. In young cultures, cells are rods about $0 \cdot 7 \mu \mathrm{m}$ in width by $3 \cdot 0-4 \cdot 0 \mu \mathrm{m}$ in length. In old cultures, rods become shorter or spherical. Colonies are circular, convex with entire margins, moist, shiny and light yellow in colour. Does not grow in an anaerobic chamber at $37^{\circ} \mathrm{C}$. The temperature range for growth is $20-37^{\circ} \mathrm{C}$, with optimal growth at $30^{\circ} \mathrm{C}$. The $\mathrm{pH}$ range for growth is $6 \cdot 0-8 \cdot 0$, with optimal growth at $\mathrm{pH} 7 \cdot 0$. No growth occurs at an $\mathrm{NaCl}$ concentration of more than $10 \%$; optimal growth occurs without added $\mathrm{NaCl}$. Strains give positive results for aesculin hydrolysis, for catalase and for acid production from glucose, fructose, mannose, rhamnose, mannitol, $N$-acetylglucosamine, cellobiose, maltose, sucrose and starch. Weakly positive for acid production from D-xylose, galactoside, trehalose, glycogen and D-turanose. Negative for oxidase, nitrate reduction, indole production, glucose acidification, arginine hydrolysis, urease, gelatin hydrolysis, $\beta$-galactosidase and acid production from glycerol, erythritol, D-arabinose, L-arabinose, ribose, L-xylose, adonitol, methyl $\beta$-D-xyloside, sorbose, dulcitol, inositol, sorbitol, methyl $\alpha$-D-mannoside, methyl $\alpha$-D-glucoside, amygdalin, arbutin, salicin, lactose, melibiose, inulin, melezitose, raffinose, xylitol, gentiobiose, Dlyxose, D-tagatose, D-fucose, L-fucose, D-arabitol, L-arabitol, gluconate, 2-ketogluconate and 5-ketogluconate. The G $+\mathrm{C}$ content of the DNA is $68 \mathrm{~mol} \%$, the major isoprenoid quinones are MK-11 and MK-12, and the major cellular fatty acids are anteiso- $\mathrm{C}_{15: 0}$, anteiso- $\mathrm{C}_{17: 0}$ and iso- $\mathrm{C}_{16: 0}$. The cell-wall sugars are galactose and xylose. The diamino acid in the cell-wall hydrolysates is lysine.

The type strain is JS53-2 ${ }^{\mathrm{T}}\left(=\mathrm{KCTC} 19074^{\mathrm{T}}=\mathrm{CIP} 108696^{\mathrm{T}}=\right.$ CCUG $50754^{\mathrm{T}}$ ), isolated from sea water in the South Sea of Korea (the Korea Strait).

\section{Acknowledgements}

The authors would like to thank Professor Hans G. Trüper for his advice on naming of the organisms. This research was supported by a grant from the KRIBB Research Initiative Program.

\section{References}

Behrendt, U., Ulrich, A. \& Schumann, P. (2001). Description of Microbacterium foliorum sp. nov. and Microbacterium phyllosphaerae sp. nov., isolated from the phyllosphere of grasses and the surface litter after mulching the sward, and reclassification of Aureobacterium resistens (Funke et al. 1998) as Microbacterium resistens comb. nov. Int J Syst Evol Microbiol 51, 1267-1276.

Bousfield, I. J., Keddie, R. M., Dando, T. R. \& Shaw, S. (1985). Simple rapid methods of cell wall analysis as an aid in the identification of aerobic coryneform bacteria. In Chemical Methods in Bacterial Systematics, vol. 20, pp. 221-236. Edited by M. Goodfellow \& D. E. Minnikin. London: Academic Press.

Collins, M. D., Jones, D., Keddie, R. M., Kroppenstedt, R. M. \& Schleifer, K. H. (1983). Classification of some coryneform bacteria in a new genus Aureobacterium. Syst Appl Microbiol 4, 236-252.

Ezaki, T., Hashimoto, Y. \& Yabuuchi, E. (1989). Fluorometric deoxyribonucleic acid-deoxyribonucleic acid hybridization in microdilution wells as an alternative to membrane filter hybridization in 
which radioisotopes are used to determine genetic relatedness among bacterial strains. Int J Syst Bacteriol 39, 224-229.

Felsenstein, J. (1985). Confidence limits on phylogenies: an approach using the bootstrap. Evolution 39, 783-791.

Felsenstein, J. (1993). PHYLIP (phylogeny inference package), version 3.5c. Distributed by the author. Department of Genome Sciences, University of Washington, Seattle, USA.

Jukes, T. H. \& Cantor, C. R. (1969). Evolution of protein molecules. In Mammalian Protein Metabolism, pp. 21-132. Edited by H. N. Munro. New York: Academic Press.

Komagata, K. \& Suzuki, K. (1987). Lipid and cell-wall analysis in bacterial systematics. Methods Microbiol 19, 201-203.

Lee, J.-S., Jung, M.-C., Kim, W.-S. \& 10 other authors (1996). Identification of lactic acid bacteria from kimchi by cellular FAMEs analysis. Korean J Appl Microbiol Biotechnol 24, 234-241.

Marmur, J. (1961). A procedure for the isolation of DNA from microorganisms. J Mol Biol 3, 208-218.

Orla-Jensen, S. (1919). The Lactic Acid Bacteria. Copenhagen: Host \& Sons.

Rossello-Mora, R. \& Amann, R. (2001). The species concept for prokaryotes. FEMS Microbiol Rev 25, 39-67.

Saitou, N. \& Nei, M. (1987). The neighbor-joining method: a new method for reconstructing phylogenetic trees. Mol Biol Evol 4, 406-425.

Shin, Y. K., Lee, J.-S., Chun, C. O., Kim, H.-J. \& Park, Y.-H. (1996). Isoprenoid quinone profiles of the Leclercia adecarboxylata KCTC $1036^{\mathrm{T}}$. J Microbiol Biotechnol 6, 68-69.

Skerman, V. B. D. (1967). A Guide to the Identification of the Genera of Bacteria, 2nd edn. Baltimore: Williams \& Wilkins.

Stackebrandt, E. \& Goebel, B. M. (1994). Taxonomic note: a place for DNA-DNA reassociation and $16 \mathrm{~S}$ rRNA sequence analysis in the present species definition in bacteriology. Int J Syst Bacteriol 44, 846-849.
Stackebrandt, E. \& Liesack, W. (1993). Nucleic acids and classification. In Handbook of New Bacterial Systematics, pp. 152-189. Edited by M. Goodfellow \& A. G. O'Donnell. London: Academic Press.

Stackebrandt, E., Frederiksen, W., Garrity, G. M. \& 10 other authors (2002). Report of the ad hoc committee for the re-evaluation of the species definition in bacteriology. Int J Syst Evol Microbiol 52, 1043-1047.

Takeuchi, M. \& Hatano, K. (1998a). Union of the genera Microbacterium Orla-Jensen and Aureobacterium Collins et al. in a redefined genus Microbacterium. Int J Syst Bacteriol 48, 739-747.

Takeuchi, M. \& Hatano, K. (1998b). Proposal of six new species in the genus Microbacterium and transfer of Flavobacterium marinotypicum ZoBell and Upham to the genus Microbacterium as Microbacterium maritypicum comb. nov. Int J Syst Bacteriol 48, 973-982.

Tamaoka, J. \& Komagata, K. (1984). Determination of DNA base composition by reversed phase high-performance liquid chromatography. FEMS Microbiol 25, 125-128.

Thompson, J. D., Higgins, D. G. \& Gibson, T. J. (1994). CLUSTAL W: improving the sensitivity of progressive multiple sequence alignment through sequence weighting, position-specific gap penalties and weight matrix choice. Nucleic Acids Res 22, 4673-4680.

Wayne, L. G., Brenner, D. J., Colwell, R. R. \& 9 other authors (1987). International Committee on Systematic Bacteriology. Report of the ad hoc committee on reconciliation of approaches of bacterial systematics. Int J Syst Bacteriol 37, 463-464.

Yang, P., Vauterin, L., Vancaneyt, M., Swings, J. \& Kersters, K. (1993). Application of fatty acid methyl esters for the taxonomic analysis of the genus Xanthomonas. Syst Appl Microbiol 16, 47-71.

Yumoto, I., Yamazaki, K., Sawabe, T., Nakano, K., Kawasaki, K., Ezura, Y. \& Shinano, H. (1998). Bacillus horti sp. nov., a new Gramnegative alkaliphilic bacillus. Int J Syst Bacteriol 48, 565-571. 